\title{
Congressional Investigations:
}

\section{IMPORTANCE OF THE FACT-FINDING PROCESS}

\author{
GEORGE MEADER
}

$\mathrm{T}$

HE INVESTIGATIVE POWER of the Congress is the means through which Congress may, if it has the mind to do so, reassert the policy-making authority intended to be vested in it by the drafters of the Constitution.

Our national economy has developed amazingly in our rather brief national history of a century and a half, but our national legislature has failed to keep pace with the demands upon it for the development of sound national policies and programs in a modern, complex and mechanized society. This weakness in the Congress has resulted in the delegation to the executive branch of the government of vast legislative authority. Legislation frequently is drafted in the departments or bureaus and presented to the Congress as an administration "must" bill. Loyal administration committee chairmen or committee members are expected to force the passage of such a bill with a minimum of amendments. This weakness also has induced Congress to announce broad objectives in general terms, then create boards or commissions with extensive but looselydefined authority to accomplish these objectives. The net effect of this weakness on the part of Congress is that national policies are not originated and determined by the representatives of the people, but for the most part are originated in, then spelled out by, the executive branch of the government. This method of legislating is not in the interest of true democracy.

If this trend continues, with Congress becoming weaker and the executive branch of the government becoming stronger, the adoption of national policies through elected representatives will be a mere fiction. When that time arrives the equilibrium designed by those who drafted our Constitution will have been upset, and the protection of our citizens, through the system of checks and balances, from abuses of public power will have vanished. Equilibrium will be restored between the executive and the legislative branches only when Congress so equips itself that it can inde-

$\dagger$ United States Representative (R., 2d Dist., Mich.). Formerly counsel for the TrumanMead Committee and the Fulbright Committee of the United States Senate. 
pendently, and in its own right, originate and adopt national policies, expressed in sufficient detail and in unambiguous terms, and which, in the judgment of the Congress, are in the best interest of the country.

I know of no means whereby Congress can assert its authority over national policies except through the expansion and improvement of its investigative power. In the field of debate, facts and logic are the only effective weapons. Control of the facts is control of the ultimate result. A Congress which is poorly equipped to gather facts, to sift them and make certain of their reliability, is a weak Congress. A Congress which lacks an effective fact-finding instrument is at the mercy of the executive branch of the government whose two million employees can gather information and, through omission and inclusion, through coloring and slanting, can support any program the administration cares to adyance. There is power in facts. To decide without knowing the facts is certain to lead to error and unsupportable positions.

August 7, I944, President (then Senator) Truman, in announcing on the floor of the United States Senate his resignation as Chairman of the Special Committee Investigating the National Defense Program, said:

In my opinion, the power of investigation is one of the most important powers of the Congress. The manner in which that power is exercised will largely determine the position and prestige of the Congress in the future. An informed Congress is a wise Congress; an uninformed Congress surely will forfeit a large portion of the respect and confidence of the people.

The days when Webster, Clay, and Calhoun personally could familiarize themselves with all the major matters with respect to which they were called upon to legislate are gone forever. No Senator or Representative, no matter how able or diligent, can himself hope to master all the facts necessary to legislate wisely.

The accomplishments of the Truman Committee-and I am referring now to the other members of the committee and its staff, rather than to myself - present an example of the results that can be obtained by making a factual investigation with a good staff. Similar accomplishments can be made by other special committees, as well as the standing committees of the Congress, and I particularly urge upon the Senate that it be liberal in providing ample funds for the prosecution of proper investigations. The cost of a good investigation is negligible when compared with the results which can be obtained. ${ }^{x}$

No reference to the investigative power of Congress can be found in the Constitution, yet its existence is well established.* Before our nation was born, the English Parliament and the colonial legislatures exercised investigative powers. ${ }^{2}$ The power of Congress to "send for persons and

* Consult McGeary, Historical Development, page 425 supra.

I 90 Cong. Rec. 6747 (1944).

2 Landis, Congressional Power of Investigation, 40 Harv. L. Rev. I53, I59 (I926). 
papers" is said to be a necessary adjunct to legislative power, since it enables Congress to inform and enlighten itself before enacting laws. ${ }^{3}$

The basis for implying the existence of the investigative power of Congress furnishes the guide to its proper exercise as well as the direction of its development into a more useful instrument of a democratic system of government. In our modern, complex national economy, with its intricate and multitudinous interrelationships, regulations and controls can no longer be adopted by simple, broad generalities but must be based upon thorough knowledge of the detailed facts, the conflicting special interests and the general public interest. The effects of proposed legislative action may thus be intelligently calculated, wise policies decided upon, and enactments stated in clear and unambiguous terms.

Primarily what Congress requires to expand and strengthen its investigative activities is the will to do so. Possessing the power to appropriate, Congress can spend on its own activities such sums as it believes necessary to discharge properly its policy-making function. In the preparation of this article, I sought to learn what information existed to show, for various periods in this nation's history, the size of investigative staffs employed by the Congress.

The only immediately available comparison is that in I944 the combined professional and clerical staffs of all the committees of both the House of Representatives and the Senate numbered 52I, while in I950-in the Second Session of the 8Ist Congress-the total was 6I4. Of the latter, 290 were professional people and 324 were clerical. This information, although sketchy, indicates:

First, that in the past six years, there has been no pronounced expansion in investigative staffs. This is particularly so when it is remembered that the Legislative Reorganization Act of $1946^{4}$ authorized four professional and six clerical positions for each committee.

Second, committee staffs, considered as a whole, are small in relation to the tremendous responsibilities of the Congress, since they amount, even including clerical personnel, to about one staff member for each member of Congress.

It might be said that two things are prerequisite to more intensive investigation: first, the will to investigate, and, second, the staff. With respect to the will to investigate, there probably has been no dearth of resolutions offered by individual legislators throughout the years, urging that this or that phase of our national activity be investigated. As is the case

3 McGrain v. Daugherty, 273 U.S. 135 (1927).

460 Stat. 812 (I946). 
with legislative bills, many of these resolutions never get beyond the stage of reference to a committee and, indeed, some of them may not have been seriously pressed by their sponsors. A study of the history of such resolutions would be interesting and might disclose reasons why Congress, in the past, failed to develop its investigative activities so as to keep pace with the very rapid growth and development of our national economy.

It is suggested that one reason for the lack of investigative activity is that efforts to look into matters which might embarrass the administration have been suppressed by committee chairmen and other influential legislators friendly to the administration. A further explanation is that it may have seemed to legislators that there is presently so much demand upon their time for legislative work and for service to their constituents that they are reluctant to assume the additional burden of extended inquiries. A still further reason might exist in the reluctance of some legislators to appoint investigative staffs for fear that the credit and publicity attendant upon an investigation might go to the hired investigator rather than to the legislator. It appears to me that none of the foregoing possible reasons for the reluctance of Congress to expand its investigative activities have any basic validity.

Congressmen and senators should be friendly and co-operative with the executive branch of the government. But they should never lose sight of the fact that under our Constitution their responsibility is to the electors, and that they are sworn to exercise their independent judgment in enacting policies in the public interest. Undue subservience to the executive departments and agencies, who, through the use of public money appropriated to them, frequently have been able to lobby effectively, is out of harmony with the basic constitutional philosophy of the separation of powers.

Lack of time is no valid excuse for failure to investigate. The importance of sound, factual knowledge, as a basis for legislation, is so great that other activities of a legislator must give way to the development of salient facts, without which an intelligent and wise policy cannot be determined. Through organization and delegation of functions, supervised and controlled by the legislators, the fact-finding job can be performed by subordinates without excessive drain on the personal time of the legislator.

One need only to reflect momentarily on the wording of statutes which authorize the President to perform certain acts, which he, in turn, redelegates to the two million or more employees in the federal government, to realize that the drains on the personal time of the individual legislator can be lessened if he is provided with adequate assistance. 
Neither should there be any competition for publicity and credit. This matter should clearly be within the control of the legislator and the committee, since the right to discipline subordinates for the issuance of statements to the press is inherent in the control of the committee over its staff. In fact, it is unsound for the responsibility for statements of policy, or, statements of fact resulting from investigative work, to be delegated to one who is not directly responsible to the electorate. Of course, it is necessary for a legislator or committee to rely upon the work of committee investigators, but whatever is done is the act of the legislator and not the subordinate. The head of any organization cannot shirk responsibility for the discharge of functions vested in him.

The failure of Congress to acquire adequate investigative staffs is difficult to justify. One suggested reason is that, although Congress appropriates billions of dollars to executive departments, it is very niggardly when spending money on itself, for fear of retaliation by the electorate. I cannot say whether indiscriminate propaganda has originated in the executive branch of the government, with the purpose of curbing congressional activity and maintaining the power of the executive branch over legislation. Neither can I say whether the press, with or without any malicious intent, emphasizes and exaggerates any mean or low qualities which may appear in congressmen and senators. These may provide some basis for the fears of individual congressmen that the expenditure of any substantial sum of money on Congress itself might result in their subsequent defeat at the polls. But, in my judgment, this is far from a wellfounded reason for Congress' failure to expand its investigative activities.

I believe that if Congress properly presented its case to the public, efforts to place its action in an unfavorable light would fail. I believe the temper of the people is such that a curb on the executive power through the more effective exploration of specific federal activities would be popular under present conditions. I believe the people could readily understand that the expenditure of a few million dollars on the strengthening of Congress and its means of obtaining information about public affairs could well result in the saving of billions of dollars in the operation of the executive branch of the government.

Instances of nepotism, kick-backs and other reprehensible activities on the part of individual congressmen in the past, which have been so well publicized, might mitigate against public acceptance of an expanded staff for Congress. For this reason, it is extremely important that individual legislators refrain from using for their personal gain any funds provided for the discharge of their public functions. Also, it is important that Con- 
gress itself call attention to such instances when they occur and discipline members who disregard their public trust.

In the selection of investigative staffs, it is important that extreme care be exercised. Persons should be chosen for their unquestioned loyalty to the Congress (it is an undesirable practice to borrow personnel from the executive branch of the government), for their care in exploring questions which may be submitted to them for investigation, for their impartiality, for their discretion, and for their diligence. The success of an investigation probably depends more upon the quality of the personnel conducting it than upon any technique, precepts or rules which can be stated.

I can visualize no way Congress can be induced to expand and improve its investigative activities except through a natural growth resulting from competent and successful investigations. It seems to me that investigations which enjoy wide public acceptance, and bring deserved credit to those conducting them, may well awaken the interest of other legislators in initiating investigations, and, at the same time, enjoin upon them a high level of statesmanship in their conduct. Positions on investigative staffs should be made sufficiently attractive so that men of ability can afford to accept them. Properly-developed investigations can not only provide Congress with factual information necessary to intelligent decisions, but can also test the arguments for and against a particular course of action.

When legislation comes to be based more upon studies of fact and less upon generalities, emotions and prejudices, our system of government by the people through elected representatives will have proved itself workable in a modern, complex society. 